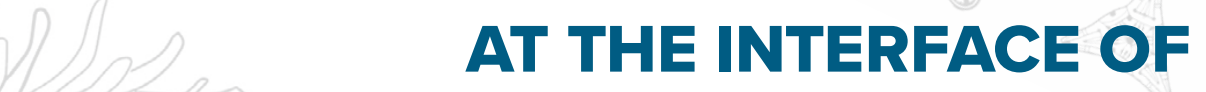 MARINE DISCIPLINES Use of Autonomous Seafloor Equipment for Studies of Biofouling Below the Shallow-Water Zone \\ By Alexandra Chava, Anna Gebruk, Glafira Kolbasova, Artem Krylov, Alexei Tanurkov, Andrei Gorbuskin, Olga Konovalova, Dragosh Migali, Yulia Ermilova, Nikolay Shabalin, Vladimir Chava, Igor Semiletov, and Vadim Mokievsky
}

ABSTRACT. Biofouling of artificial substrates is a well-known phenomenon that can negatively impact offshore industry operations as well as data collection in the ocean. Fouling communities worldwide have mostly been studied within the top $50 \mathrm{~m}$ of the ocean surface, while biofouling below this depth remains largely underreported. Existing methods used to study biofouling are labor intensive and expensive when applied to the deep sea. Here, we propose a simple and cost-effective modification of traditional methods for studying biofouling by mounting test plates on autonomous seafloor equipment and preserving them in ethanol upon retrieval for transport to the laboratory. This method can greatly advance our understanding of biofouling processes in the deeper ocean, including fouling community biodiversity, recruitment, and seasonality. We present two case studies from the Laptev Sea and the Sea of Okhotsk in support of this method. In the first study, we looked at fouling communities on the surfaces of ocean-bottom seismometers deployed for one year in the 36-350 m depth range. In the second study, we tested metal and plexiglass (poly(methyl methacrylate) plates mounted on autonomous bottom stations and found evidence of both micro- and macrofouling after three months of deployment. Our results demonstrate that various autonomous seafloor equipment can be used as supporting platforms for biofouling studies.

\section{AIMS AND SCOPE OF THE STUDY}

The expansion of human activities into deep sea areas is leading to an increase in the number of man-made structures on the seafloor below the shallow-water zone (<50 m depth; Jouffray et al., 2020). These structures provide a new type of habitathard substrate on or above the soft, sedimented bottom (e.g., Degraer et al., 2020). The development, composition, and abundance of biofouling organisms on these structures are much less studied than those in the shallow waters (Cowie, 2010). Only patchy observations exist on the temporal scale of the biofouling process on hard substrates below $50 \mathrm{~m}$ depth (e.g., Apolinario and Coutinho, 2009; Cowie, 2010; Bellou et al., 2012; Degraer et al., 2020). Thus, our understanding of biofouling temporal and spatial scales, and its variation with depth, is limited. One way to increase the amount of data available for addressing the development of fouling communities is collection of long-term observations using replicates of different duration (e.g., Hutchison et al., 2020). These time- and effortconsuming studies are usually based on specially designed installations mounted at different depths (e.g., Railkin, 2004).

Here, we propose a simple approach for collecting biofouling observations along with primary hydrological and geophysical data. The small addition of test panels to standard oceanographic instrumentation can help to fill the gaps in our understanding of the development of biofouling communities in lesser-known areas. Here, we first present a literature review of the state of knowledge of marine biofouling to introduce the field's terms, concepts, and knowledge gaps. We then present two case studies that support our proposed approach to collecting biofouling information, followed by identification of further steps, recommendations, and research opportunities that will improve our understanding of biofouling with increasing water depth in the ocean.

\section{MARINE BIOFOULING}

Marine biofouling, defined as settlement and growth of marine organisms on artificial submerged surfaces (Woods Hole Oceanographic Institution, 1952), has been known since the first vessels set sail thousands of years ago. Today, biofouling impacts a wide variety of human activities with adverse technical and economic repercussions. Fouling organisms can heavily encrust the hulls of ships, negatively affecting speed performance and leading to increased fuel consumption (Townsin, 2003). Hydroelectric power plant refrigeration systems and other industrial installations connected to the sea can be negatively affected by fouling 
assemblages (Apolinario and Coutinho, 2009). Biofouling is a serious problem for the oil and gas industry because it causes fatigue damage and results in a dramatic increase in hydrodynamic loading of offshore platforms (Yan and Yan, 2003; Page et al., 2010). Offshore wind farms' submerged structures provide surfaces where artificial reefs form, affecting ecosystem structure and functioning and likely impacting fisheries (Degraer et al., 2020). Fouling communities can also enhance corrosion and physically damage surfaces and equipment (Whomersley and Picken, 2003; Page et al., 2010). In addition, biofouling can serve as a vector for biological invasions, with vessels transporting fouling species outside their areas of natural distribution (Gollasch, 2002).

Due to these negative impacts, industries protect man-made structures either by using preventative measures or by removing fouling organisms, methods that can be harmful to the environment. For example, the use of antifouling paints to prevent recruitment of fouling organisms raises ecotoxicological concerns, as copper is one of the most popular antifouling components (Turner, 2010; Miller et al., 2020). Comprehensive understanding of how fouling communities evolve is an essential step toward developing more effective, safe, and sustainable approaches to mitigating biofouling of artificial substrates. Knowledge about the key features of the fouling community, such as species composition of different stages, growth rates, and breeding patterns, allow scientists to predict the development of biofouling more accurately. However, our knowledge of fouling communities remains scarce in the areas below the top $50 \mathrm{~m}$ of the ocean.

FIGURE 1. Conceptual model of fouling community composition showing four major stages (molecular fouling, particulate fouling, microfouling, and macrofouling) and the main groups of organisms (based on Wahl, 1989; Clare et al., 1992; Railkin, 2004). The arrows show that all stages are connected and influence each other and the substrate.

\section{DEVELOPMENT OF MARINE BIOFOULING COMMUNITIES}

Fouling community assemblages consist of a wide range of species that include but are not limited to bacteria, fungi, algae, bryozoans, hydrozoans, sponges, molluscs, polychaetes, and crustaceans (Apolinario and Coutinho, 2009). Factors that determine recruitment and development of fouling communities include: (a) duration and seasonality of exposure to the substrate, (b) substrate morphology and physical and chemical properties, (c) depth, (d) oceanographic conditions, (e) availability of bacteria and larvae in the surrounding environment, and (f) macromolecular composition of the environment (Clare et al., 1992; Turner and Todd, 1993; Railkin, 2004).

High temporal and spatial variability characterize recruitment of fouling assemblages (Turner and Todd, 1993); nevertheless, the major components of biofouling communities can be defined as molecular fouling, particulate fouling, and micro- and macrofouling. Molecular and particulate fouling include adsorption of various biological macromolecules and organic and inorganic particles that are controlled mainly by physical forces (Baier, 1984; Clare et al.,
1992). Microfouling is dominated by bacteria and diatoms but may also include other unicellular algae, fungi, archaea, and protozoa (Dobretsov and Rittschof, 2020). These organisms form a complex three-dimensional structure called a biofilm. Macrofouling is formed by algal spores and various larvae of sessile invertebrates that settle on the surface of the substrate and then develop into adult individuals (Wahl, 1989; Railkin, 2004). Macrofouling may include all taxa of macroalgae as well as a wide variety of sessile animals-most commonly hydroids, bryozoans, sea anemones, barnacles and other cirripedians, sedentary polychaetes, bivalves, sponges, and ascidians. Though there are several individual cases where a distinct successional pattern can be detected (see Wahl, 1989; Clare et al., 1992; Oshurkov, 1992; Railkin, 2004; Zvyagintsev, 2005, for discussion and examples), the stages identified in these studies do not necessarily follow each other in strict progression. Rather, they form a system in dynamic balance (Clare et al., 1992).

Figure 1 presents the principal scheme of major components of fouling communities based on a synthesis of available scientific literature.

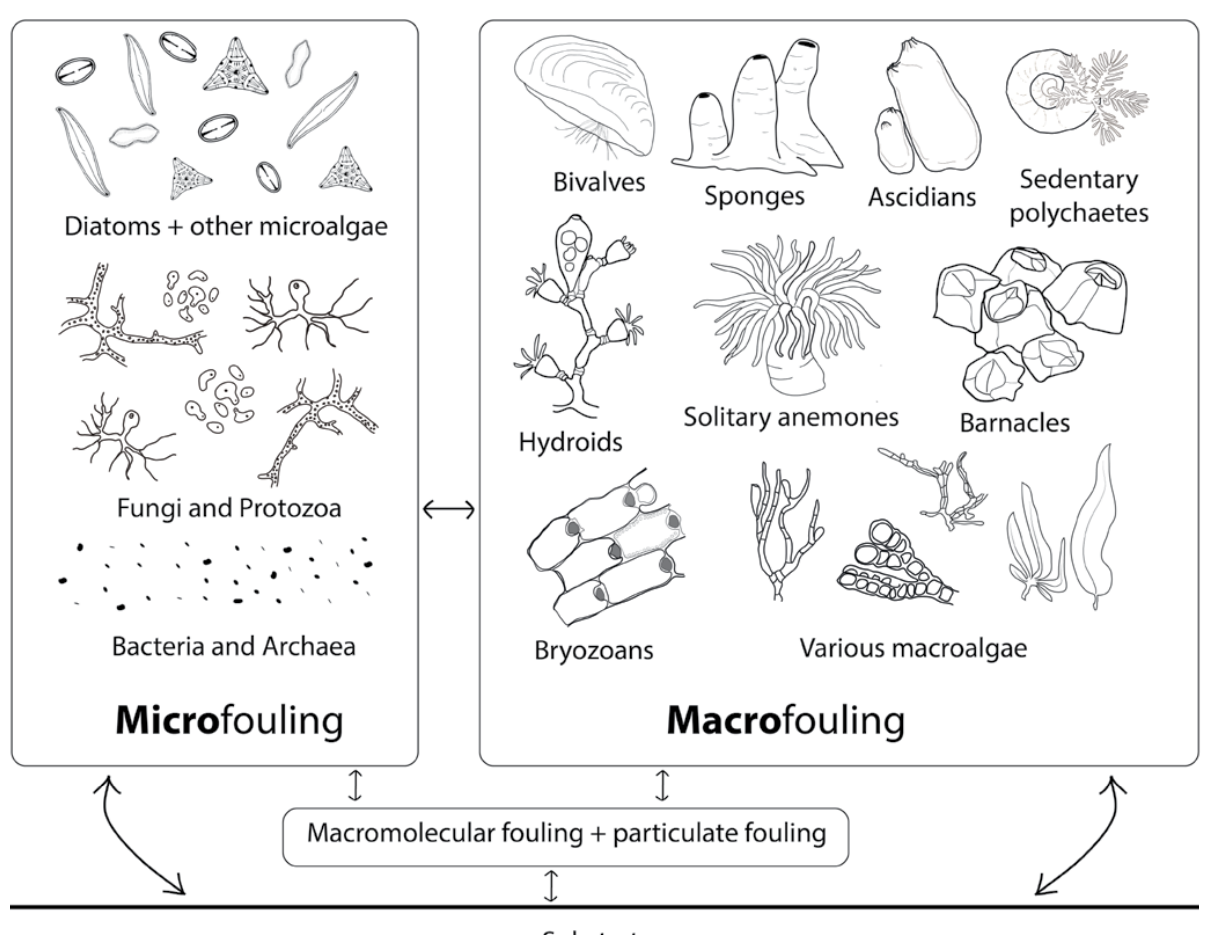

Substrate 


\section{METHODS OF}

\section{BIOFOULINC STUDIES}

Studies of fouling communities on manmade structures have been mostly conducted at water depths down to $50 \mathrm{~m}$ in response to various technical needs, such as power plant engineering, aquaculture, or maintenance of ships and piers (Cowie, 2010). The methods traditionally used for these studies can be divided into two large groups.

Observational research has been conducted since people first started to notice and record the presence of fouling organisms on ship hulls and man-made coastal structures. Subjects of numerous studies include signal buoys, piers, breakwaters, bridges (Kay and Butler, 1983; Oshurkov, 1992; Qvarfordt et al., 2006; Venkatesan et al., 2017), oil platforms, and wind turbines (Stachowitsch et al., 2002; Andersson and Öhman, 2010; Degraer et al., 2020). Recent developments in underwater photography and video resolution have enhanced observational methods (e.g., Kogan et al., 2006; Gormley et al., 2018). In addition, remotely operated vehicles have enabled researchers to expand observations into deeper areas of the ocean (Hudson et al., 2005).

Researchers are passive spectators in observational studies, while experimental studies allow control of different aspects of the biofouling process, including type and state of the substrate, exposure time, and study location. Test plates made of glass, metal, or plastic (with or without additional coatings) are commonly used as artificial substrates to monitor development of fouling communities, especially in shallow waters (e.g., Terlizzi et al., 2000; Jelic-Mrcelic et al., 2006; Satheesh and Wesley, 2011; Vedaprakash et al., 2013). Test plates have a number of advantages for biofouling studies, namely (1) simplicity and low cost of production and installation; (2) no limitations on study duration-plates can be used for hours, days, weeks, months, or years; and (3) convenience of sample collectionplates can be easily detached, preserved, and transported to a laboratory.
Experimental plates are usually submerged in shallow waters for periods ranging from several days (Dziubińska and Szaniawska, 2010) to several months or years (Hirata, 1992).

\section{BIOFOULING VARIATION WITH INCREASING DEPTH}

In the past 30 years, the expansion of offshore industries into deeper ocean areas (below $50 \mathrm{~m}$ ) has introduced artificial substrates into new biomes. With increasing depth, fewer naturally occurring hard substrates are available for colonization by planktonic larvae of fouling organisms. This makes artificial substrates especially attractive and leads to formation of diverse and complex fouling communities on a wide range of hard substrates such as shipwrecks, pipes, or oil platform supporting structures (e.g., Kogan et al., 2006; Meyer et al., 2016). Despite numerous examples of deep-sea biofouling of artificial substrates, researchers still do not know the exact sequence of events that results in these deep-sea "oases of life." The complexity of environmental gradients with increasing depth prevents scientists from direct extrapolation of existing knowledge about shallow-water biofouling patterns to patterns in deeper waters. Similar to shallow waters, in the deep sea there are likely multiple processes that can influence the development of fouling communities. The following key factors change with increasing depth:

1. Decreasing light results in decline of primary production and the role of vegetation in fouling until there is a complete absence of algae and phytoplankton from biofouling communities below the photic zone (Terry and Picken, 1986; Irving and Connell, 2002).

2. Decreasing temperature and increasing pressure require different physiological adaptations that only certain groups of organisms can develop (Newell and Branch, 1980; Cowie, 2010).

3. Limited food supply that results from decreasing primary production requires organisms to rely on other sources of organic matter, such as marine snow, or to develop new ways of producing organic matter themselves, as chemosynthetic organisms do (Cowie, 2010).

4. Scarcity of hard substrates in the deep sea alters the larval pool composition and renders the resulting community less predictable.

5. Faunistic borders that determine community structure are more complicated in the deep sea than on the continental shelf, where they are usually connected to algal distribution (Hedgpeth, 1957).

6. Larval densities become lower with increasing depth (Gaines et al., 2007), which in turn influences the recruitment process and therefore the resulting community structure.

Variations of each of these parameters with depth can depend on latitude, local oceanographic conditions, and bottom topography.

Although distribution, variation with depth, and faunistic borders have been established for many benthic communities, these aspects have never been examined in detail for fouling communities. Available data on deep-sea biofouling globally remain sporadic and descriptive, with few quantitative studies on biodiversity and ecological or biogeographical patterns of fouling communities below $50 \mathrm{~m}$ depth. Although there are important publications dedicated to biofouling in some deep-sea ecosystems (i.e., hydrothermal vents and cold seeps; Guezennec et al., 1998; Alain et al., 2004; W.P. Zhang et al., 2014; Lee et al., 2014), their results cannot be extrapolated to the other regions due to the very specific environmental conditions they consider. Several studies of the deep-sea biofouling communities were conducted in a collaboration between oil and gas companies and research institutions; one example is the SERPENT (Scientific and Environmental ROV Partnership using Existing iNdustrial Technology) project (Hudson et al., 2005). Regional data on biofouling are often linked to the 
positioning of offshore structures (e.g., in China - Yan and Yan, 2003, and H. Zhang et al., 2015; in Brazil - Apolinario and Coutinho, 2009; in the UK - Forteath et al., 1982), whereas the rest of the open ocean remains largely underexplored. Although numerous studies have demonstrated that deep-sea micro- and macrofoulers can colonize and damage artificial substrates such as wood, plastic, cotton rope, and various metal alloys (e.g., Muraoka, 1966; Berger and Berger, 1986; Guezennec et al., 1998; Kogan et al., 2006), a broad review of biofouling by Cowie (2010) noted a worldwide lack of information on biofouling patterns with depth that remains accurate a decade later.

\section{USE OF AUTONOMOUS SEAFLOOR EQUIPMENT IN BIOFOULING OBSERVATIONS}

Paucity of experimental biofouling studies deeper than $50 \mathrm{~m}$ can be explained by the technological, logistical, and financial difficulties of installing test plates in deeper areas, especially below $300 \mathrm{~m}$. One way to address this knowledge gap is by using seafloor equipment as monitoring platforms to support biofouling research. Experimental plates can simply be mounted on autonomous seafloor equipment for the duration of a study and thus significantly increase the geographical area and reduce the costs of biofouling research. Any autonomous seafloor research equipment that remains stationary for a substantial period of time has the potential to accommodate biofouling test plates. Current profilers, acoustic buoys, and bottom seismic stations are just a few examples. Another promising platform type is slow-moving remotely operated vehicles, which can be used for studying short-term (up to several hours) biofouling processes.

FIGURE 2. Case study locations in (a) the Laptev Sea (ocean bottom seismometers), and (b) the Sea of Okhotsk (autonomous bottom stations).
Two case studies on biofouling in underexplored areas of the Laptev Sea (Eurasian Arctic) and the Sea of Okhotsk (western Pacific) are presented below. The first investigates fouling communities recruited on the surfaces of six ocean-bottom seismometers (OBSs) after a year of deployment in the Laptev Sea (Figure 2a). The second focuses on provisional results from biofouling test plates installed for three months on two autonomous bottom stations (ABSs) in the Sea of Okhotsk (Figure 2b).

\section{CASE STUDY 1. LAPTEV SEA, OCEAN- BOTTOM SEISMOMETERS}

Six OBSs were examined for the presence of fouling organisms after a year of exposure in the Laptev Sea. The instruments were deployed from R/V Akademik Mstislav Keldysh during cruise AMK-73 in September-October 2018 and collected a year later during cruise AMK-78 in September-October 2019. The depth varied from $36 \mathrm{~m}$ for OBS-3 to $350 \mathrm{~m}$ for OBS- 6 on the margin of continental slope (Figure 2). The upper layer of the bottom sediments over the whole research area consisted of silty-sandy ooze. The Laptev Sea is a marginal sea of the Arctic Ocean known for harsh weather conditions, the presence of thick ice for most of the year, and low benthic biodiversity (Spiridonov et al., 2011).

Two types of OBSs were used: seismometers 1-5 (all model "МПССР") featured a solid duralumin encasement set on a cement base, and OBS- 6 (model "GEONOD") had a plastic (polypropylene) encasement with apertures and a glass sphere body underneath (Figure 3 ). Following retrieval, the OBSs were visually examined and photographed. All visible fauna were manually detached from the surfaces and preserved in $96 \%$ ethanol for further identification, after which random scrubber samples were taken to assess smaller animals and microfouling.

Marine organisms were found on the exposed outer surfaces of the OBSs, on both dialuminium and plastic cases, as well as inside the modules (on the surface of the glass sphere for GEONOD and on the inner surface of the cement base for МПССР), and on the buoy ropes. Notably, surfaces were also partly covered with silt and mud.

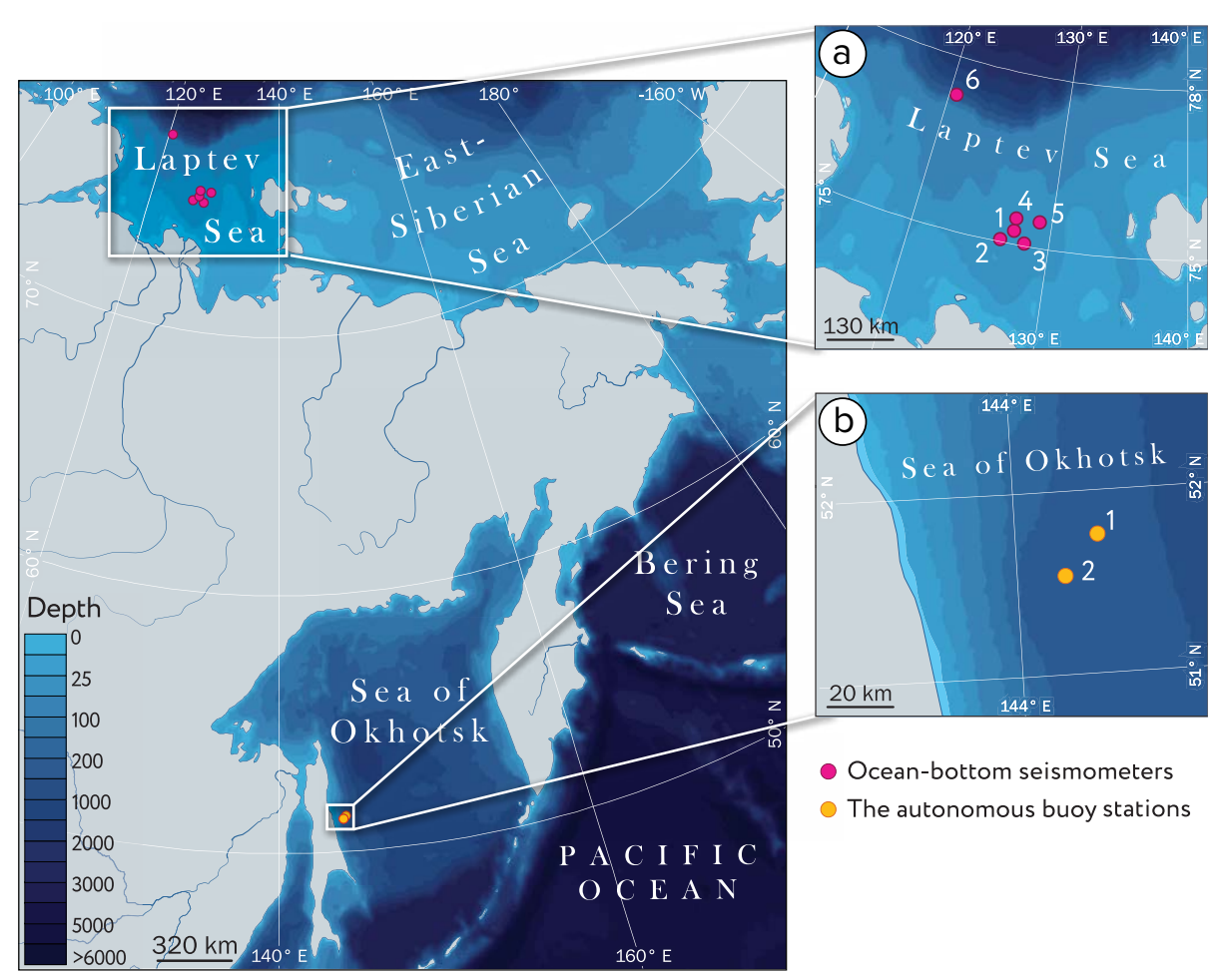


FIGURE 3. Two models of ocean bottom seismometers (OBSs) before (on the left) and after (on the right) deployment for one year in the Laptev Sea.

Seventeen species of benthic invertebrates were identified, including polychaetes, cnidarians, isopods and other crustaceans, echinoderms, gastropod molluscs (and their eggs), and nemertean worms. These species can be divided into mobile and sessile fauna. Species were likely attracted by high local variability of substrates and surfaces and were presumably foraging on sessile organisms. Table 1 lists species found on each OBS and identifies their modality (sessile/ mobile), abundance, and biomass.

Cnidarians, including hydroids (Obelia longissima; Tubularia indivisa), sea anemones (Stomphia coccinea), and a soft coral species Gersemia fruticosa were the only sessile species found. Hydroids Obelia longissima (Figure 4) were abundant not only on OBS surfaces but also on ropes and buoys. Similar fouling success has been reported previously due to high growth rate and capacity, and protective mechanisms against certain predators, including nudibranchs and pantopods (Osman, 1977; Butler and Chesson, 1990; Butler and Connolly, 1999).

Isopods Synidotea bicuspida were found in large numbers on one of the seismometers and likely hatched out of the egg clutches. Most of the other mobile species were represented by just one animal. More data are needed to look at patterns in species distribution. The outer surface of OBS- 6 was heavily encrusted with eggs of the gastropod Buccinum glaciale (Figure 4), and numerous empty shells were found beneath the encasement.

Key factors determining colonization success of different species on OBS surfaces likely included larval settlement period, breeding season, and longevity of the species recruited (Osman, 1977; Greene and Schoener, 1982; Whomersley and Picken, 2003).

\section{CASE STUDY 2.}

\section{SEA OF OKHOTSK, AUTONOMOUS BOTTOM STATIONS}

The second study was conducted in the Sea of Okhotsk, a marginal sea of the western Pacific Ocean, using autonomous bottom stations that were submerged from July 17 to October 16, 2019, approximately $50 \mathrm{~km}$ east of Sakhalin Island at depths from $45 \mathrm{~m}$ to $230 \mathrm{~m}$ (Figure 2). Biofouling test plates were mounted on two acoustic Doppler current profiler (ADCP) buoys at each site. A total of eight test plates were used with one poly(methyl methacrylate)

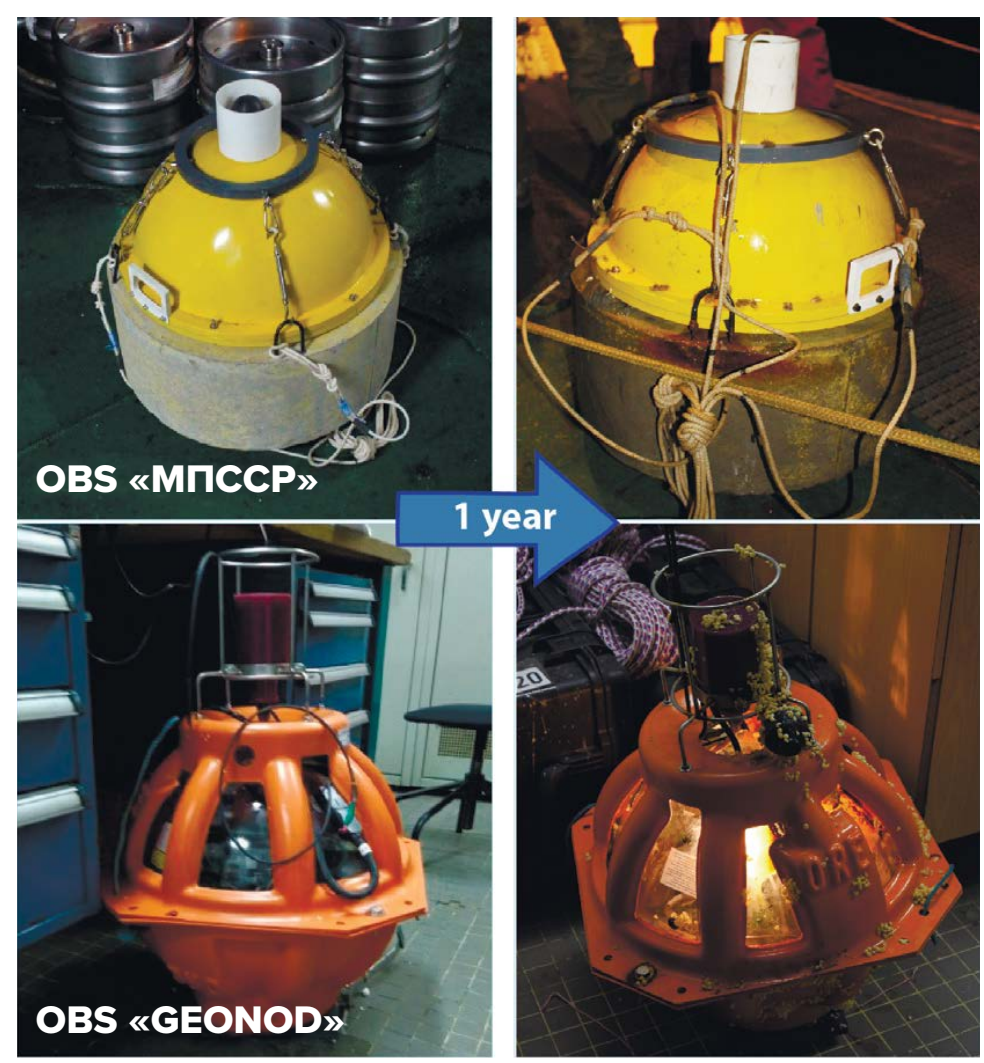

TABLE 1. List of species found on six ocean-bottom seismometers during Akademik Mstislav Keldysh cruise 78 after a year of deployment on the seafloor. For each species, their number and biomass (in g, in brackets) and modality (sessile/mobile) are shown. Non-zero values are highlighted with blue shading.

\begin{tabular}{|c|c|c|c|c|c|c|}
\hline \multirow{2}{*}{ LIST OF SPECIES (GROUP) } & OBS-1 & OBS-2 & OBS-3 & OBS-4 & OBS-5 & OBS-6 \\
\hline & \multicolumn{6}{|c|}{ Number per sample (biomass, g) } \\
\hline \multicolumn{7}{|l|}{ Annelida } \\
\hline \multirow{2}{*}{$\begin{array}{l}\text { Amphitrite cirrata }(\mathrm{M}) \\
\text { Nereis zonata }(\mathrm{M})\end{array}$} & & & & $1(0.52)$ & & \\
\hline & & & & $1(0.29)$ & & $2(0.42)$ \\
\hline \multicolumn{7}{|l|}{ Cnidaria } \\
\hline \multirow{5}{*}{$\begin{array}{l}\text { Gersemia fruticosa (S) } \\
\text { Obelia longissima (S) } \\
\text { Stomphia coccinea (S) } \\
\text { Tubularia indivisa (S) } \\
\text { Actiniaria Gen. sp. (S) }\end{array}$} & & $1(2.21)$ & & & & \\
\hline & + & & + & & & \\
\hline & & & & & $2(17.20)$ & \\
\hline & & $1(4.51)$ & $1(0.35)$ & & & \\
\hline & & & & & & $3(2.79)$ \\
\hline \multicolumn{7}{|l|}{ Crustacea } \\
\hline \multirow{3}{*}{$\begin{array}{l}\text { Eualus gaimardii (M) } \\
\text { Socarnes vahlii (M) } \\
\text { Synidotea bicuspida (M) }\end{array}$} & & & & & & $1(1.17)$ \\
\hline & $2(1.68)$ & & & & & \\
\hline & & $26(6.28)$ & & & & \\
\hline \multicolumn{7}{|l|}{ Echinodermata } \\
\hline \multirow{3}{*}{$\begin{array}{l}\text { Gorgonocephalus arcticus (M) } \\
\text { Heliometra glacialis (M) } \\
\text { Ophiura sarsii (M) }\end{array}$} & & & & & $2(14.17)$ & \\
\hline & & & $1(31.31)$ & & & \\
\hline & & $1(2.07)$ & $1(3)$ & & & \\
\hline \multicolumn{7}{|l|}{ Mollusca } \\
\hline \multirow{2}{*}{$\begin{array}{l}\text { Buccinum glaciale (M) } \\
\text { Margarites groenlandicus (M) }\end{array}$} & & & & & & $\begin{array}{l}3(2.81) \\
+ \text { eggs }\end{array}$ \\
\hline & & & & & $2(0.15)$ & \\
\hline \multicolumn{7}{|l|}{ Nemertea } \\
\hline \multirow{2}{*}{$\begin{array}{l}\text { Cerebratulus sp. (M) } \\
\text { Gen. sp. (M) }\end{array}$} & $1(2.01)$ & & & & & \\
\hline & & $1(0.39)$ & & $1(0.55)$ & $1(0.47)$ & \\
\hline
\end{tabular}

$\mathrm{M}=$ mobile. $\mathrm{S}$ = sessile. + Indicates presence of animals that were not quantitatively estimated due to large size of the colonies. 

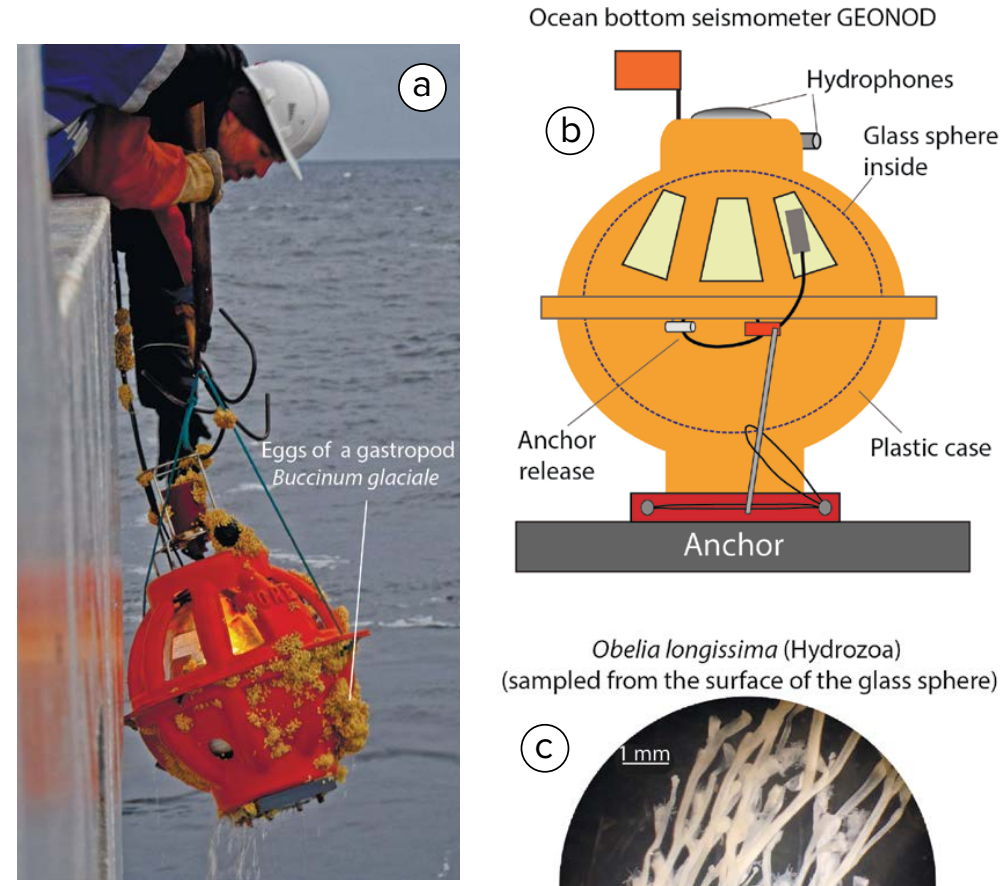

Obelia longissima (Hydrozoa) (sampled from the surface of the glass sphere)
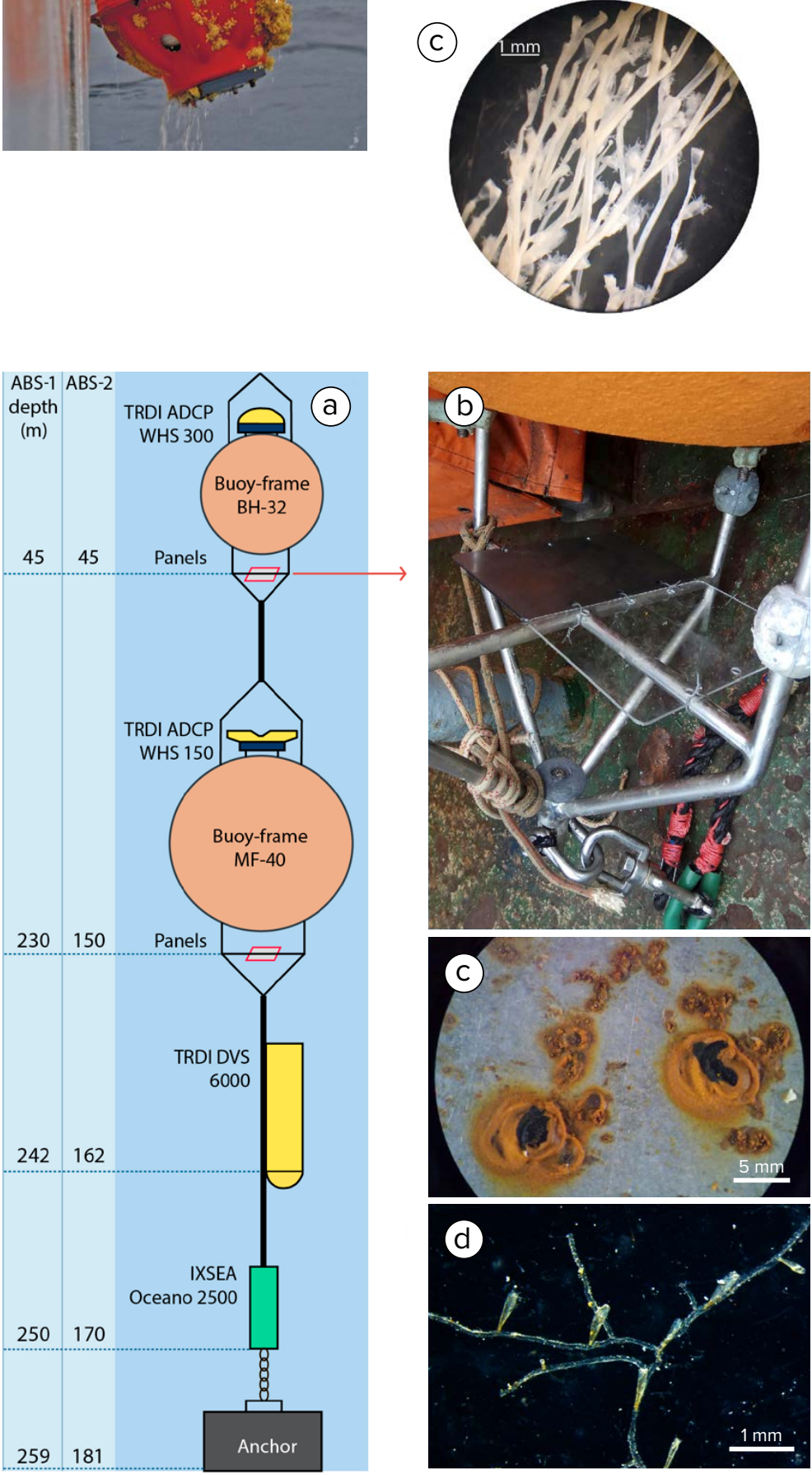

FIGURE 4. (a) Retrieval of the GEONOD ocean-bottom seismometer during Akademik Mstislav Keldysh cruise 78, with eggs of Buccinum glaciale on its surface. (b) Schematic drawing of the GEONOD seismometer model. (c) Hydroid Obelia longissima found on the GEONOD OBS.

plate and one raw steel plate attached to each of the four buoys. Each plate measured $21 \mathrm{~cm} \times 29.7 \mathrm{~cm}$. Figure 5a shows a detailed schematic of an ABS with test plates attached.

The ABSs were retrieved after the three-month deployment, and the test plates were detached, preserved in $70 \%$ ethanol, and later examined for the presence of fouling organisms.

\section{Steel Plates}

Both sides (one facing the water surface and the other facing the seafloor) of all four plates showed evidence of biofouling. Microbial communities modified the smooth surfaces of the plates into more complex pitted landscapes suitable for settlement of the larvae of eukaryotic fouling species (Figure 5c). Samples of the biofilm from each plate were examined using light microscopy (Leica DM 2500). Numerous bacterial colonies were observed (Figure 6a), and various crystals of unknown origin were detected in the bacterial mass (Figure $6 b, c$ ). The cubic forms in Figure $6 \mathrm{~b}$ are likely salt crystals, and the long, thin forms in Figure $6 \mathrm{c}$ may be sponge spicules. Total biofouling cover on the plates was visually estimated to be $97 \%-100 \%$. In some areas, the coverage exceeded $100 \%$, as the bacterial community formed complex three-dimensional structures. No traces of multicellular organisms were found on the steel plates.

According to numerous studies of marine microbial corrosion (e.g., Iverson, 1987; McBeth and Emerson, 2016), the first and most abundant colonizers of steel are iron-oxidizing bacteria. Further identification of the members of this bacterial assemblage would require complex genetic analysis as well as scanning electron microscopy, techniques that are beyond the scope of this study. However, such research is important, as understanding of the

FIGURE 5. Schematic of an autonomous bottom station (ABS) with test plates attached (red panels). (a) ADCP = acoustic Doppler current profiler. DVS = Doppler volume sampler. IXSEA = acoustic release. (b) Photo of plexiglass and metal test plates attached to the metal buoy frame before submersion. (c) After three months at $230 \mathrm{~m}$ depth, the raw steel panel showed traces of bacterial corrosion. (d) Hydroids were established on the plexiglass plate after three months at $150 \mathrm{~m}$. 
patterns of microbial corrosion can substantially advance our knowledge of biofouling processes.

\section{Plexiglass (Polymethyl Methacrylate) Plates}

Two plexiglass plates mounted on the lower frame of ABS BH-32 at $45 \mathrm{~m}$ depth showed no signs of any visible microor macrofouling. Another two plexiglass plates submerged at greater depths (150 $\mathrm{m}$ and $230 \mathrm{~m}$ ) showed two different stages of colonization, with more complex biofouling organisms found on the plexiglass surfaces than on the steel plate surfaces. Traces of complex microfouling (various sessile protists from phylum Ciliata) and macrofouling (hydroids and barnacles) were detected on the plates.

After analyzing the fauna on the recovered test plates, we concluded that our experimental design could be improved by roughening the plexiglass test plates. Surface roughness increases suitability for settlement of rugophilic fouling organisms (those that thrive on rough surfaces or in surface cavities; e.g., Wisely, 1959; Köhler et al., 1999; Baldanzi et al., 2021).

The plate from ABS-2, submerged at $150 \mathrm{~m}$ depth, contained communities of sessile Ciliata on both sides. On one side we found two species of ciliates, subclass Suctoria: Ephelota gemmipara (Hertwig, 1875) and Acineta compressa (Claparède \& Lachmann, 1859), and one colonial species from the subclass Peritrichia, which we could not identify due to its poor condition (Figure 7). There was also an undamaged small specimen of a hydroid (order Thecata, six empty calicles) that we could not identify beyond the order level (Figure 5d). E. gemmipara dominated numerically with its density estimated as $55 \pm 4$ ind $\mathrm{cm}^{-2}$. The density of Peritrichia was lower at $20 \pm 10$ ind $\mathrm{cm}^{-2}$. A. compressa was found in small groups of 10-20 individuals. In total, we found 16 groups on the upper side of the plate. On the other side of the plate, the species composition of ciliates was the same, though E. gemmipara was less abundant $\left(17 \pm 2\right.$ ind $\left.\mathrm{cm}^{-2}\right)$ and the unknown spe- cies of Peritrichia was much more abundant $\left(146 \pm 23\right.$ ind $\left.\mathrm{cm}^{-2}\right)$.

The plate from ABS-1, located at $230 \mathrm{~m}$ depth, contained one juvenile barnacle (f. Balanidae, presumably Chirona evermanni, $2 \mathrm{~mm}$ in diameter) and a few individuals of severely damaged E. gemmipara on the one side, while the other side was free of any visible macro- or microfouling.

\section{FURTHER STEPS, RECOMMENDATIONS, AND RESEARCH OPPORTUNITIES}

The case studies in the Laptev Sea and the Sea of Okhotsk demonstrate that ocean-bottom seismographs and autonomous bottom stations are both suitable as support platforms for biofouling test plates. Although collection of samples from equipment surfaces is possible, the main benefits of using test plates include simplicity and low cost of manufacturing and installation as well as ease of sample preservation for further quantitative analyses. Supplementary Table S1 provides examples of equipment that can be used for biofouling studies based on analyses of maximum deployment time and depth limits; this list is provisional and should be expanded.

Using test plates mounted on a variety of seafloor autonomous equipment can greatly advance baseline data on biofouling for poorly studied areas of the ocean. Standardized protocols needed for such studies include those for plate construction, preservation of samples, and analyses. Further test studies involving different equipment, different deployment times and depths, and varied oceanographic conditions would inform development of such protocols. In addition to using the test plates, opportunities to collect biological material from the equipment itself

FIGURE 6. Colonies of iron-oxidizing bacteria were found on the steel plates at all depths $(400$ x). (a) General view of a bacterial mass comprised of differently colored parts that presumably indicate different species or stages. $(b, c)$ Various crystals of unknown origin were found in the bacterial mass. should not be neglected. H. Zhang et al. (2015) and our case study in the Laptev Sea demonstrate that samples from the surfaces of seafloor equipment can also contain valuable data on fouling community characteristics. Standardized protocols are also needed for observation and sampling of biofouling on various equipment surfaces.

Test plates deployed for the duration of independent projects or research cruises can provide valuable data; however, a more holistic approach would involve
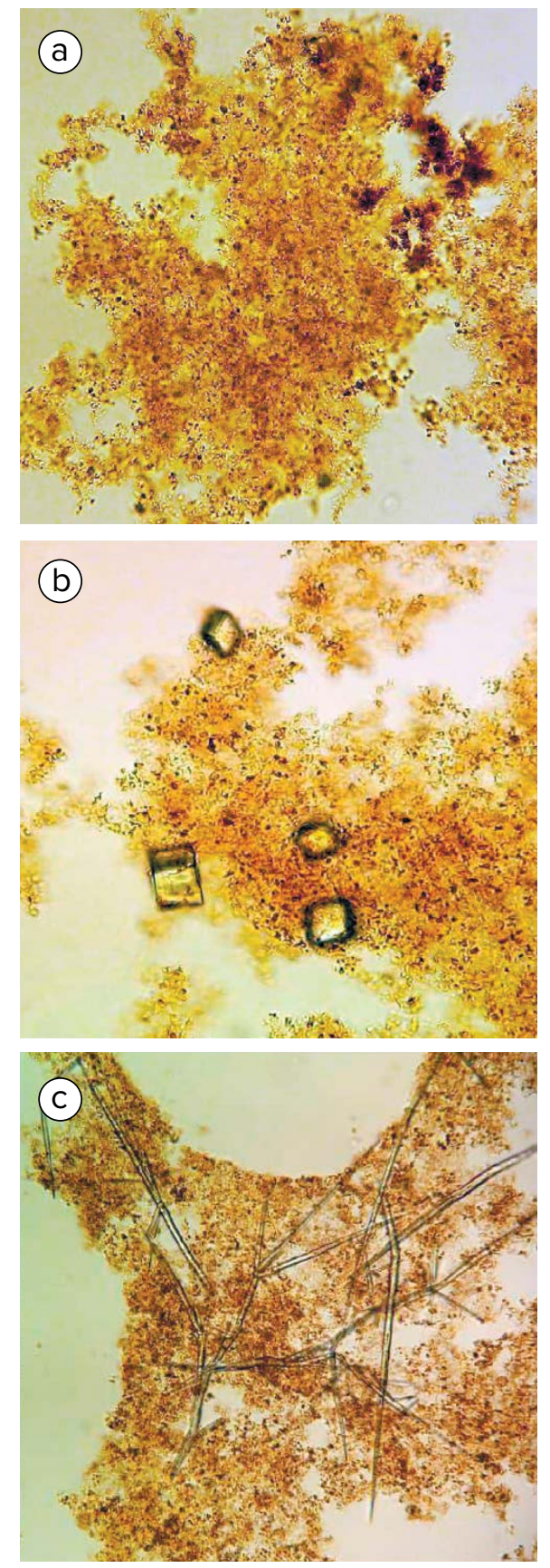
FIGURE 7. Microfouling species found on the plexiglass plate mounted on ABS-2. (a) Lateral view of the upper part of an individual Ephelota gemmipara (Ciliata, Suctoria) with tentacles. (b) Lateral view of the upper part of an individual Acineta compressa (Ciliata, Suctoria). (c) General view of several colonies of unidentified Peritrichia (Ciliata). (d) Closer image of single "heads" of Peritrichia (Ciliata)

adding systematic implementation of biofouling studies to such integrated observing systems as the International Long-Term Ecological Research Network (Muelbert et al. 2019), Ocean Observatories Initiative, or regional networks of the Global Ocean Observing System. The infrastructure of these observing systems that could be useful for biofouling investigations include advanced autonomous data collection equipment such as deep-sea moorings, profilers, gliders, and autonomous underwater vehicles. Mooring arrays are of particular interest for biofouling studies as they provide means to deploy multiple test plates at fixed depths for prolonged periods of time.

The data on biological fouling below photic depths are not only of great scientific interest but also have practical applications. Offshore industries expanding to the deep sea will face new challenges related to biofouling of man-made structures that must be understood in order to develop effective prevention. Adding fouling control experiments to the protocols for environmental assessments could provide crucial information for protection from biofouling. In addition, fouling communities pose potential threats to autonomous equipment operating on the seafloor, particularly instruments equipped with optical lenses or highly sensitive sensors (Lehaitre et al., 2008). Potential bias caused by effects of fouling organisms can be reduced by developing a better understanding of their recruitment, diversity, community development, and variation with depth.

Key knowledge gaps that need to be addressed in future biofouling studies include, but are not limited to:
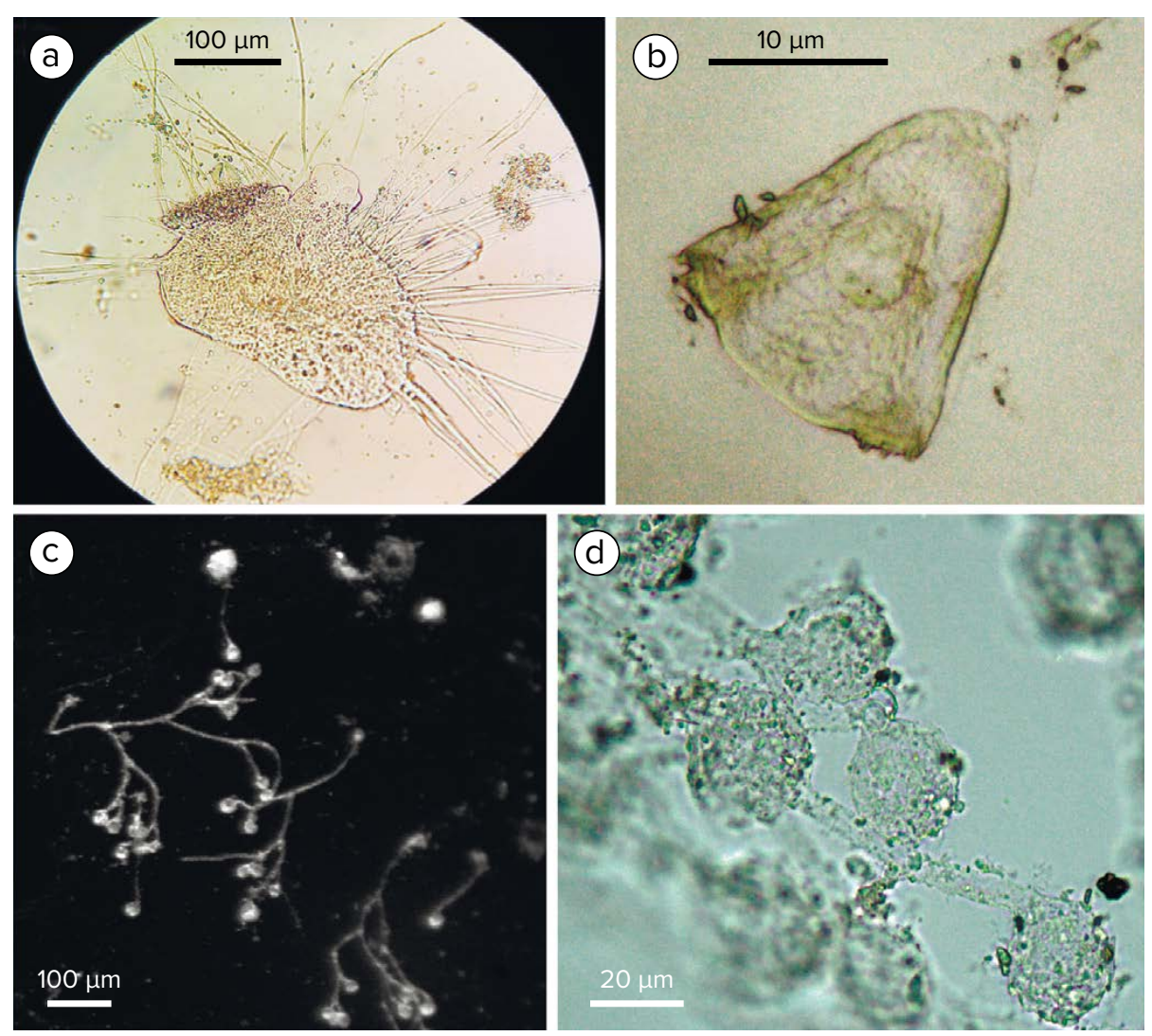

- Biodiversity of fouling communities deeper areas that may be affected by combelow $50 \mathrm{~m}$ depth in different geographical areas, particularly in the understudied and actively exploited polar regions.

- Variation of developmental patterns in biofouling communities with depth.

- Dynamics of biological fouling in the long term (>1 year).

- Variation in the drivers of recruitment in biofouling communities with depth.

\section{CONCLUSIONS}

While biological fouling is a well-known process, it has been mostly studied in shallow waters ( $<50 \mathrm{~m}$ depth), driven by development of coastal communities (e.g., ship and pier maintenance) and technological needs of marine industries (e.g., power plants, aquaculture). However, the effect that fouling communities have on the substrate-ranging from the increase in hydrodynamic loading to biocorrosion speedup-should not be underestimated for all depths.

We cannot simply extrapolate existing knowledge from shallow waters to plicated environmental gradients, light and substrate limitations, and differing organisms. While an understanding of deep-sea biofouling is important from a scientific perspective, it is also needed to protect underwater structures and seafloor equipment.

Specially prepared test plates are broadly used in shallow-water experimental biofouling studies. Here, we have explored how they can be applied in a deepwater setting. Use of autonomous seafloor equipment as platforms for mounting biofouling test plates has proven to be a simple and cost-effective method to greatly advance the geographical and depth ranges of biofouling studies. Although the results of our case studies do not provide enough data for comprehensive analyses of the diversity of fouling communities at depths below $50 \mathrm{~m}$, our observations provide strong evidence of biofouling on both steel and test plates can be successfully mounted on OBSs and ABSs for recruitment of plexiglass plates and demonstrate that 
fouling communities below the shallowwater zone. We suggest that the list of equipment suitable for biofouling studies can be further extended, and standardized protocols for such work need to be developed. We urge researchers working in various marine disciplines to consider including biofouling testing in their operations. @

\section{SUPPLEMENTARY MATERIALS}

Table S1 is available online at https://doi.org/10.5670/ oceanog.2021.302.

\section{REFERENCES}

Alain, K., M. Zbinden, N. Le Bris, F. Lesongeur, J. Quérellou, F. Gaill, and M.A. Cambon-Bonavita. 2004. Early steps in microbial colonization processes at deep-sea hydrothermal vents. Environmental Microbiology 6(3):227-241, https://doi.org/10.1111/j.1462-2920.2003.00557.x.

Andersson, M.H., and M.C. Öhman. 2010. Fish and sessile assemblages associated with windturbine constructions in the Baltic Sea. Marine and Freshwater Research 61(6):642-650, https://doi.org/10.1071/MF09117.

Apolinario, M., and R. Coutinho. 2009. Understanding the biofouling of offshore and deep-sea structures. Pp. 132-147 in Advances in Marine Antifouling Coatings and Technologies. C. Hellio and D. Yebra, eds, Woodhead Publishing, Cambridge, UK, https://doi.org/10.1533/9781845696313.1.132.

Baier, R.E. 1984. Initial events in microbial film formation. Pp. 57-62 in Marine Biodeterioration: An Interdisciplinary Study. J.D. Costlaw and R.D. Tipper, eds, Naval Institute Press, Annapolis, Maryland.

Baldanzi, S., I.T. Vargas, F. Armijo, M. Fernández, and S.A. Navarrete. 2021. Experimental assessment of a conducting polymer (PEDOT) and microbial biofilms as deterrents and facilitators of macro-biofouling: Larval settlement of the barnacle Notobalanus flosculus (Darwin, 1854) from Central Chile. Journal of Marine Science and Engineering 9(1):82, https://doi.org/10.3390/jmse9010082.

Bellou, N., E. Papathanassiou, S. Dobretsov, V. Lykousis, and F. Colijn. 2012. The effect of substratum type, orientation and depth on the development of bacterial deep-sea biofilm communities grown on artificial substrata deployed in the Eastern Mediterranean. Biofouling 28(2):199-213, https://doi.org/10.1080/08927014.2012.662675.

Berger, L.R., and J.A. Berger. 1986. Countermeasures to microbiofouling in simulated ocean thermal energy conversion heat exchangers with surface and deep ocean waters in Hawaii. Applied and Environmental Microbiology 51(6):1,186-1,198, https://doi.org/10.1128/AEM.51.6.1186-1198.1986.

Butler, A.J., and P.L. Chesson. 1990. Ecology of sessile animals on sublittoral hard substrata: The need to measure variation. Australian Journal of Ecology 15(4):521-531, https://doi.org/10.1111/ j.1442-9993.1990.tb01475.x.

Butler, A.J., and R.M. Connolly. 1999. Assemblages of sessile marine invertebrates: Still changing after all these years? Marine Ecology Progress Series 182:109-118, https://doi.org/10.3354/ meps182109.

Clare, A.S., D. Rittschof, D.J. Gerhart, and J.S. Maki. 1992. Molecular approaches to nontoxic antifouling. Invertebrate Reproduction \& Development 22(1-3):67-76, https://doi.org/ 10.1080/07924259.1992.9672258.
Cowie, P.R. 2010. Biofouling patterns with depth. Pp. 87-99 in Biofouling. S. Durr and J.C. Thomason, eds, Blackwell Publishing, Oxford, UK, https://doi.org/10.1002/9781444315462.ch6.

Degraer, S., D.A. Carey, J.W.P. Coolen, Z.L. Hutchison, F. Kerckhof, B. Rumes, and J. Vanaverbeke. 2020. Offshore wind farm artificial reefs affect ecosystem structure and functioning: A synthesis. Oceanography 33(4):48-57, https://doi.org/ 10.5670/oceanog.2020.405.

Dobretsov, S., and D. Rittschof. 2020. Love at first taste: Induction of larval settlement by marine microbes. International Journal of Molecular Sciences 21(3):731, https://doi.org/10.3390/ ijms21030731.

Dziubińska, A., and A. Szaniawska. 2010. Shortterm study on the early succession stages of fouling communities in the coastal zone of Puck Bay (southern Baltic Sea). Oceanological and Hydrobiological Studies 39(4):3-16, https://doi.org/ 10.2478/v10009-010-0055-z.

Forteath, G.N.R., G.B. picken, R. Ralph, and J. Williams. 1982. Marine growth studies on the North Sea oil platform Montrose Alpha. Marine Ecology Progress Series 8(1):61-68, https://www.jstor.org/ stable/24814623.

Gaines, S.D., D.B. Gaylor, L.R. Gerber, A. Hastings, and B.P. Kinlan. 2007. Connecting places: The ecological consequences of dispersal in the sea. Oceanography 20(3):90-99, https://doi.org/ 10.5670/oceanog. 2007.32 .

Gollasch, S. 2002. The importance of ship hull fouling as a vector of species introductions into the North Sea. Biofouling 18(2):105-121, https://doi.org/ 10.1080/08927010290011361.

Gormley, K., F. McLellan, C. McCabe, C. Hinton, J. Ferris, D.I. Kline, and B.E. Scott. 2018. Automated image analysis of offshore infrastructure marine biofouling. Journal of Marine Science and Engineering 6(1):2, https://doi.org/10.3390/ jmse6010002.

Greene, C.H., and A. Schoener. 1982. Succession on marine hard substrata: A fixed lottery. Oecologia 55(3):289-297, https://doi.org/10.1007/ BF00376914.

Guezennec, J., O. Ortega-Morales, G. Raguenes, and G. Geesey. 1998. Bacterial colonization of artificial substrate in the vicinity of deep-sea hydrothermal vents. FEMS Microbiology Ecology 26(2):89-99, https://doi.org/10.1111/j.1574-6941.1998.tb00495.x.

Hedgpeth, J.W. 1957. Classification of marine environments. Pp. 93-102 in Treatise on Marine Ecology and Paleoecology. GSA Memoir vol. 67, v2, H.S. Ladd, ed., https://doi.org/10.1130/ MEM67V2-p93.

Hirata, T. 1992. Succession of sessile organisms on experimental plates immersed in Nabeta Bay, Izu Peninsula, Japan V. An integrated consideration on the definition and prediction of succession. Ecological Research 7(1):31-42, https://doi.org/ 10.1007/BF02348595.

Hudson, I.R., D.O.B. Jones, and B.D. Wigham. 2005. A review of the uses of work-class ROVs for the benefits of science: Lessons learned from the SERPENT project. Underwater Technology 26(3):83-88, https://doi.org/10.3723/ 175605405784426637.

Hutchison, Z.L., M. LaFrance Bartley, S. Degraer, P. English, A. Khan, J. Livermore, B. Rumes, and J.W. King. 2020. Offshore wind energy and benthic habitat changes: Lessons from Block Island Wind Farm. Oceanography 33(4):58-69, https://doi.org/ 10.5670/oceanog.2020.406.

Irving, A.D., and S.D. Connell, S.D. 2002. Sedimentation and light penetration interact to maintain heterogeneity of subtidal habitats: Algal versus invertebrate dominated assemblages. Marine Ecology Progress Series 245:83-91, https://doi.org/10.3354/meps245083.

Iverson, W.P. 1987. Microbial corrosion of metals. Advances in Applied Microbiology 32:1-36, https://doi.org/10.1016/S0065-2164(08)70077-7.

Jelic-Mrcelic, G., M. Sliskovic, and B. Antolic. 2006. Biofouling communities on test panels coated with TBT and TBT-free copper based antifouling paints. Biofouling 22(5):293-302, https://doi.org/ 10.1080/08927010600912291.

Jouffray, J.B., R. Blasiak, A.V. Norström, H. Österblom, and M. Nyström. 2020. The blue acceleration: The trajectory of human expansion into the ocean. One Earth 2(1):43-54, https://doi.org/10.1016/ j.oneear.2019.12.016.

Kay, A.M., and A.J. Butler. 1983. 'Stability' of the fouling communities on the pilings of two piers in South Australia. Oecologia 56(1):70-78, https://doi.org/ 10.1007/BF00378219.

Kogan, I., C.K. Paull, L.A. Kuhnz, E.J. Burton, S. Von Thun, H.G. Greene, and J.P. Barry. 2006 ATOC/Pioneer Seamount cable after 8 years on the seafloor: Observations, environmental impact. Continental Shelf Research 26(6):771-787, https://doi.org/10.1016/j.csr.2006.01.010.

Köhler, J., P.D. Hansen, and M. Wahl. 1999 Colonization patterns at the substratum-water interface: How does surface microtopography influence recruitment patterns of sessile organisms? Biofouling 14(3):237-248, https://doi.org/10.1080/ 08927019909378415.

Lee, O.O., Y. Wang, R. Tian, W. Zhang, C.S. Shek, S. Bougouffa, A. Al-Suwailem, Z.B. Batang, W. Xu, G.C. Wang, and X. Zhang. 2014. In situ environment rather than substrate type dictates microbial community structure of biofilms in a cold seep system. Scientific Reports 4(1):1-10, https://doi.org/10.1038/ srep03587.

Lehaitre, M., L. Delauney, and C. Compère. 2008. Biofouling and underwater measurements. Pp.463-493 in Real-Time Observation Systems for Ecosystem Dynamics and Harmful Algal Blooms: Theory, Instrumentation and Modelling. M. Babin, C.S. Roesler, and J.J. Cullen, eds, UNESCO, Paris.

McBeth, J.M., and D. Emerson. 2016. In situ microbial community succession on mild steel in estuarine and marine environments: Exploring the role of iron-oxidizing bacteria. Frontiers in Microbiology 7:767, https://doi.org/10.3389/ fmicb.2016.00767.

Meyer, K.S., C.M. Young, A.K. Sweetman, J. Taylor, T. Soltwedel, and M. Bergmann. 2016. Rocky islands in a sea of mud: Biotic and abiotic factors structuring deep-sea dropstone communities. Marine Ecology Progress Series 556:45-57, https://doi.org/10.3354/meps11822.

Miller, R.J., A.S. Adeleye, H.M. Page, L. Kui, H.S. Lenihan, and A.A. Keller. 2020. Nano and traditional copper and zinc antifouling coatings: Metal release and impact on marine sessile invertebrate communities. Journal of Nanoparticle Research 22:1-15, https://doi.org/10.1007/ s11051-020-04875-x.

Muelbert, J.H., N.J. Nidzieko, A.T. Acosta, S.E. Beaulieu, A.F. Bernardino, E. Boikova, T.G. Bornman, B. Cataletto, K. Deneudt, E. Eliason, and others. 2019. ILTER-The International LongTerm Ecological Research Network as a platform for global coastal and ocean observation. Frontiers in Marine Science 6:527, https://doi.org/10.3389/ fmars.2019.00527.

Muraoka, J.S. 1966. Deep-Ocean Biodeterioration of Materials. Report R-456, U.S. Naval Civil Engineering Laboratory, California, https://doi.org/ 10.5962/bhl.title.47743. 
Newell, R.C., and G.M. Branch. 1980. The influence of temperature on the maintenance of metabolic energy balance in marine invertebrates. Pp. 329-396 in Advances in Marine Biology, vol. 11. J.H.S. Blaxter, F.S. Russell, and M. Yonge, eds, Academic Press, Cambridge, Massachusetts, https://doi.org/10.1016/S0065-2881(08)60304-1.

Oshurkov, V.V. 1992. Succession and climax in some fouling communities. Biofouling 6(1):1-12, https://doi.org/10.1080/08927019209386205.

Osman, R.W. 1977. The establishment and development of a marine epifaunal community. Ecologica Monographs 47(1):37-63, https://doi.org/10.2307/ 1942223.

Page, H.M., J.E. Dugan, and F. Piltz. 2010. Fouling and antifouling in oil and other offshore industries. Pp. 252-266 in Biofouling. S. Durr and J.C. Thomason, eds, Blackwell Publishing, Oxford, UK, https://doi.org/10.1002/9781444315462.ch18.

Qvarfordt, S., H. Kautsky, and T. Malm. 2006. Development of fouling communities on vertical structures in the Baltic Sea. Estuarine, Coastal and Shelf Science 67(4):618-628, https://doi.org/ 10.1016/i.ecss.2006.01.004.

Railkin, A.I. 2004. Marine Biofouling: Colonization Processes and Defenses. CRC Press LLC, Boca Raton, Florida, $303 \mathrm{pp}$

Satheesh, S., and S.G. Wesley. 2011. Influence of submersion season on the development of test panel biofouling communities in a tropical coast. Estuarine, Coastal and Shelf Science 94(2):155-163, https://doi.org/10.1016/ j.ecss.2011.06.011.

Spiridonov, V.A., M.V. Gavrilo, E.D. Krasnova, and N.G. Nikolaeva, eds. 2011. Atlas of Marine and Coastal Biological Diversity of the Russian Arctic. WWF, Moscow, 64 pp.

Stachowitsch, M., R. Kikinger, J. Herler, P. Zolda, and E. Geutebrück. 2002. Offshore oil platforms and fouling communities in the south ern Arabian Gulf (Abu Dhabi). Marine Pollution Bulletin 44(9):853-860, https://doi.org/10.1016/ S0025-326X(02)00085-1.

Terlizzi, A., E. Conte, V. Zupo, and L. Mazzella. 2000. Biological succession on silicone fouling-release surfaces: Long-term exposure tests in the harbour of Ischia, Italy. Biofouling 15(4):327-342 https://doi.org/10.1080/08927010009386322.

Terry, L.A., and G.B. Picken. 1986. Algal fouling in the North Sea. Pp. 179-192 in Studies in Environmental Science, vol. 28. L.V. Evans and K.D. Hoaglan, eds, Elsevier, Amsterdam, Netherlands, https://doi.org/ 10.1016/S0166-1116(08)72179-4.

Townsin, R.L. 2003. The ship hull fouling penalty. Biofouling 19(S1):9-15, https://doi.org/10.1080/ 0892701031000088535.

Turner, S.J., and C.D. Todd. 1993. The early development of epifaunal assemblages on artificial substrata at two intertidal sites on an exposed rocky shore in St. Andrews Bay, NE Scotland. Journal of Experimental Marine Biology and Ecology 166(2):251-272, https://doi.org/10.1016/ 0022-0981(93)90223-B.

Turner, A. 2010. Marine pollution from antifouling paint particles. Marine Pollution Bulletin 60(2):159-171, https://doi.org/10.1016/j.marpolbul.2009.12.004.

Vedaprakash, L., R. Dineshram, K. Ratnam, K. Lakshmi, K. Jayaraj, S.M. Babu, R. Venkatesan, and A. Shanmugam. 2013. Experimental studies on the effect of different metallic substrates on marine biofouling. Colloids and Surfaces $B$ : Biointerfaces 106:1-10, https://doi.org/10.1016/ j.colsurfb.2013.01.007.

Venkatesan, R., J. Kadiyam, P. SenthilKumar, R. Lavanya, and L. Vedaprakash. 2017. Marine biofouling on moored buoys and sensors in the
Northern Indian Ocean. Marine Technology Society Journal 51(2):22-30, https://doi.org/10.4031/ MTSJ.51.2.11.

Wahl, M. 1989. Marine epibiosis. Part I. Fouling and antifouling: Some basics aspects. Marine Ecology Progress Series 58:175-189, https://doi.org/ 10.3354/meps058175.

Whomersley, P., and G.B. Picken. 2003. Long-term dynamics of fouling communities found on offshore installations in the North Sea. Journal of the Marine Biological Association of the United Kingdom 83(5):897-901, https://doi.org/10.1017/ S0025315403008014h.

Wisely, B. 1959. Factors influencing the settling of the principal marine fouling organisms in Sydney Harbour. Marine and Freshwater Research 10(1):30-44, https://doi.org/10.1071/ MF9590030.

Woods Hole Oceanographic Institution. 1952. Marine Fouling and Its Prevention. Prepared for Bureau of Ships, United States Navy Department, WHOI Contribution No. 580, United States Naval Institute, Maryland.

Yan, T., and W.X. Yan. 2003. Fouling of offshore structures in China-A review. Biofouling 19(S1):133-138 https://doi.org/10.1080/0892701021000057927.

Zhang, H., W. Cao, Z. Wu, X. Song, J. Wang, and T. Yan. 2015. Biofouling on deep-sea submersible buoy systems off Xisha and Dongsha Islands in the northern South China Sea. International Biodeterioration \& Biodegradation 104:92-96, https://doi.org/10.1016/j.ibiod.2015.05.003.

Zhang, W.P., Y. Wang, R.M. Tian, S. Bougouffa, B. Yang, H.L. Cao, G. Zhang, Y.H. Wong, W. Xu Z. Batang, and A. Al-Suwailem. 2014. Species sorting during biofilm assembly by artificial substrates deployed in a cold seep system. Scientific Reports 4(1):1-7, https://doi.org/10.1038/srep06647.

Zvyagintsev, A. Yu. 2005. Marine Fouling in the NorthWest Part of Pacific Ocean. Dalnauka, Vladivostok 442 pp.

\section{ACKNOWLEDGMENTS}

The authors thank their colleagues Tom Grove and Nadia Jogee (Changing Oceans Group, University of Edinburgh), Eugene Yakovis, Anna Arsenieva, and Ekaterina Bubnova for fruitful discussions and comments on earlier versions of the manuscript, and are grateful to everyone involved in carrying out the case studies and data collection. The analysis of microfouling would be more complex and time-consuming without the help of Philipp Sapozhnikov and Igor Dovgal. The excellent work of the R/V Akademic Mstis/av Keldysh crew and captain is gratefully acknowledged, as is the input of the Lomonosov Moscow State University Marine Research Center and Vyacheslav Kremenetsky in facilitating the second case study and providing the opportunity to use ABSs for experimental studies. This work was conducted for the Russian state assignment (project $N^{\circ} 0128$ 2021-0004) and partially supported by the Russian Foundation of Basic Research (projects N018-0560053 and $N^{\circ} 20-05-00533$ A)

\section{AUTHORS}

Alexandra Chava (cribrilina@gmail.com) is PhD Candidate, Laboratory of Coastal Benthic Ecology, P.P. Shirshov Institute of Oceanology, Russian Academy of Sciences (RAS), Moscow, Russia. Anna Gebruk is PhD Candidate, Changing Oceans Group, School of Geosciences, The University of Edinburgh, Edinburgh, UK, and Head of International Collaboration, Lomonosov Moscow State University Marine Research Center, Moscow, Russia. Glafira Kolbasova is Researcher, Pertsov White Sea Biological Station, Lomonosov Moscow State University, Moscow, Russia. Artem Krylov is
Researcher, P.P. Shirshov Institute of Oceanology, RAS, Moscow, Russia, and Moscow Institute of Physics and Technology, Moscow, Russia. Alexei Tanurkov is a master's degree student, University Centre in Svalbard/Moscow Institute of Physics and Technology, Moscow, Russia. Andrei Gorbuskin is Researcher, Lomonosov Moscow State University, Moscow, Russia. Olga Konovalova is Researcher, Lomonosov Moscow State University Marine Research Center, Moscow, Russia. Dragosh Migali is Research Associate, Applied Research Center Oceanology LLC, Moscow, Russia. Yulia Ermilova is Leading GIS Specialist of the Cartography Department, Lomonosov Moscow State University Marine Research Center, Moscow, Russia. Nikolay Shabalin is Executive Director, Lomonosov Moscow State University Marine Research Center, Moscow, Russia. Vladimir Chava is Head of the Fleet and Expedition Department, Lomonosov Moscow State University Marine Research Center, Moscow, Russia, and Pertsov White Sea Biological Station, Lomonosov Moscow State University, Moscow, Russia. Igor Semiletov is Head, Il'ichov Pacific Oceanological Institute, Far Eastern Branch of the Russian Academy of Sciences, Vladivostok, Russia. Vadim Mokievsky is Head, Laboratory of Coastal Benthic Ecology, P.P. Shirshov Institute of Oceanology, RAS, Moscow, Russia.

\section{ARTICLE CITATION}

Chava, A., A. Gebruk, G. Kolbasova, A. Krylov A. Tanurkov, A. Gorbuskin, O. Konovalova, D. Migali, Y. Ermilova, N. Shabalin, V. Chava, I. Semiletov, and V. Mokievsky. 2021. A simple and inexpensive method for manipulating dissolved oxygen in the lab. Oceanography 34(3):61-70, https://doi.org/10.5670/ oceanog.2021.302.

\section{COPYRIGHT \& USAGE}

This is an open access article made available unde the terms of the Creative Commons Attribution 4.0 International License (https://creativecommons.org/ licenses/by/4.0/), which permits use, sharing, adaptation, distribution, and reproduction in any medium or format as long as users cite the materials appropriately, provide a link to the Creative Commons license, and indicate the changes that were made to the original content. 